\title{
MORPHOLOGICAL PARAMETERS AND HANDGRIP MUSCLE FORCE CONTRACTILE CHARACTERISTICS IN THE FIRST SELECTION LEVEL IN WATER POLO: DIFFERENCES BETWEEN U15 WATER POLO PLAYERS AND THE CONTROL GROUP
}

\author{
M. Dopsaj ${ }^{1}$,milivoj@eunet.rs, \\ Z. Mijalkovski², zoran.mijalkovski@gmail.com, \\ N. Vasilovski ${ }^{2}$, kolewp@gmail.com, \\ N. Ćopićs ${ }^{3}$ nemanjacopic@yahoo.com, \\ M. Brzaković4, miodragbrzakovicfmmsp@gmail.com, \\ M. Marković1,mm_milanm@yahoo.com \\ ${ }^{1}$ University of Belgrade, Belgrade, Serbia, \\ ${ }^{2}$ Water Polo Association of Serbia, Belgrade, Serbia, \\ 3"UNION Nikola Tesla" University, Belgrade, Serbia, \\ ${ }^{4}$ University Business Academy, Novi Sad, Serbia
}

\begin{abstract}
Aim. The research aimed to highlight the importance of morphological parameters and handgrip muscle force contractility in the selection of fifteen-year-old water polo players of various performance levels. Materials and Methods. The present research was conducted with a sample of 103 examinees, 37 out of whom belonged to the control group (CG), 33 were U15 water polo national league players (WNL), and 33 were water polo players from Serbian U15 national team (WNT). Besides the basic morphological parameters, the contractile properties of the left and right handgrip muscle force (HG_L and $\left.\mathrm{HG}_{-} \mathrm{R}\right)$ were measured exploring two separate dimensions of contractility: maximal muscle force $-F_{\max }$, and maximal explosive force $-R_{F D} D_{\max }$. Results. The research results showed the existence of a general statistically significant difference between the three groups of participants, both in morphological space (Wilks' Lambda Value: 0.333 , F relation: $11.61, \mathrm{p}=0.000$ ) and in muscle force and explosivity (Wilks' Lambda Value: 0.590 , F relation: $3.31, p=0.000$ ). In addition, the results indicated that the WNT players had higher values of $\mathrm{F}_{\max }$ and $\mathrm{RFD}_{\max }$ than the CG participants (32.8\% for $\mathrm{F}_{\max } \mathrm{HG}_{-} \mathrm{R}$ and $63.7 \%$ for RFD max $\left._{-} H_{G} \mathrm{R}_{-}\right)$and the WNL players $\left(28.8 \%\right.$ for $\mathrm{F}_{\max } \mathrm{HG}_{-} \mathrm{L}$ and $43.0 \%$ for $\left.\mathrm{RFD}_{\max \_} \mathrm{HG}_{-} \mathrm{R}\right)$. This suggests that the higher values of handgrip maximal explosive force and maximal muscle force may be attributed to adaptive training effects on their upper extremities. Conclusion. The results of the present study suggest that the contractile characteristics of the handgrip muscle force $\left(\mathrm{F}_{\max }\right.$ and $\left.\mathrm{RFD}_{\max }\right)$ as well as morphological parameters (body height and body mass) are significant in the selection of U15 water polo players.
\end{abstract}

Keywords: water polo, anthropometric characteristics, U15, hand grip, maximal force, rate of force development, selection in sport.

In the sports training processes that are used throughout the long-term preparation period in order to achieve optimal or top-level sporting results, it is necessary to organize a system for controlling and monitoring the development of particular physical characteristics in an athlete or a team that will provide feedback on their physical fitness $[11,21,23]$. The coach can then use the data to monitor the current level of development of the tested physical ability, to follow the trend of change (regression, stagnation or progress) in the performance of the athlete or the team within the planned preparation period, and to introduce corrections to the training plan and program relative to the anticipated development levels $[1,9,11]$. In general terms, the management of the training process depends on the extent to which the system for collecting information on the current state of preparedness of athletes or teams is capable of providing accurate data on all, or at least the necessarily required, aspects of physical fitness $[18,24]$. 


\section{Физиология}

In sports sciences, the main subject of study is the movement, as a simple singular manifestation of the human motoric system, or motion (locomotion), as its more complex manifestation. Neither movement nor motion can be achieved without the body system responsible for their manifestation, i.e., without the muscular system. The basic muscle characteristic is contractility, or the ability to perform a contraction. In sports analytics and diagnostics, i.e. in metrological procedures in sports, the quantifiable output measurement is the muscle force, a unit with which the level of contractile potential in isometric muscle contraction is defined. Therefore, the muscle force is the result of muscle contraction, and the characteristics of the force achieved during isometric (static) muscular contraction in function of time (F-t relation) of a particular muscle group provide fundamental information on the athlete's contractility potential [7, 8]. In other words, the given contractile characteristics represent the most important dimensions in defining the quality of the realization of human locomotion $[18,24]$.

In order for a sport such as water polo to continue developing, it is necessary to follow the latest scientific achievements and find their best practical application in the training process in order to provide optimal physical, technical and tactical preparation of water polo players. Only by continuously improving the training methods and means, fitness control and selection efficiency can elite competitive results be achieved $[4,18,23]$. Water polo, the only Olympic sport that takes place in the aquatic environment, belongs to a group of sports games in which nonstereotypical movements and situations prevail, and in which there is simultaneously a constant change in the dynamic and motoric stereotype of the game. Because of the physical demands that prevail during a match (the swimming intensity, volume, structure and techniques, the physical exertion during duel game, the ball handling techniques, etc.), the structure of the water polo game requires that all physical abilities be highly developed in top water polo players $[1,11,27,30]$.

As movements in water polo are realized from three basic positions: horizontal, vertical and combined, from which all the technical elements are carried through either with the ball (passes, receives, shots at the goal), without it (transitions, jumps, blocks, positions), or in the contacts with the opponent (duels), it can be concluded that both the water polo game and the structure of the training process are highly com- plex in terms of the long-term optimal physical, technical and tactical preparation of the players. Each phase of such preparation must take into account the age of the players, as well as the objectives and goals of the particular stage in their sports development.

Regardless of the players' position in the game, their basic anthropometric characteristics and the contractile characteristics of their arms and shoulders as the most stressed body areas represent a very important morphological and physical feature in terms of gaining a desirable advantage over the opponents. Also, the process of talent identification as a part of selection that represents a very important step in making a sound estimate of the future performance is based on the observed individual skills and general physical, physiological and psychological abilities $[4,23]$. Unfortunately, there are very few data in sports scientific literature on the anthropometric characteristics, physical traits, physical demands and capacity in young water polo players.

The aim of this paper was to define morphological and muscle force characteristics in U15 water polo players of various selection categories and to compare them with the control group in order to establish which of the variables from the measurement space can serve as indicators in the first phase of water polo selection.

\section{Methods}

This study is classified as a basic natural experiment. Body composition and handgrip (HG) contractile characteristics were measured using the quantitative approach to collecting data through a laboratory measurement protocol.

Sample. The research sample included 103 examinees, 37 out of whom belonged to the control group (CG), 33 were U15 water polo national league players (WNL), and 33 were water polo players from Serbian U15 national team (WNT). The CG participants were the seventh and eighth grade elementary school pupils from Belgrade, Kragujevac and Pančevo, while the WNL group was comprised of water polo players from clubs across Serbia; the participants in both groups were randomly selected. The criterion for the $\mathrm{CG}$ selection was that the participants did not do any sports, while the selection criterion for the WNL group was that they were standard team members of their age in their clubs. The participants from the WNT group were the players selected to the Serbian U15 water polo national team in 2015/16 and 2017/18 competitive seasons. All descriptive characteristics of the subsamples are shown in Table 1. 
Descriptive statistics of the studied variables across subsamples

Table 1

\begin{tabular}{|c|c|c|c|c|c|c|}
\hline & & $\begin{array}{c}\mathrm{CG} \\
(\mathrm{n}=37)\end{array}$ & $\begin{array}{c}\text { WNL } \\
(\mathrm{n}=33)\end{array}$ & $\begin{array}{c}\text { WNT } \\
(\mathrm{n}=33)\end{array}$ & KSZ & $\mathrm{p}$ \\
\hline & Age (yrs.) & $14,58 \pm 0,62$ & $14,47 \pm 0,47$ & $14,79 \pm 0,52$ & 0,893 & 0,421 \\
\hline \multirow{3}{*}{ 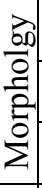 } & $\mathrm{BH}(\mathrm{cm})$ & $173,75 \pm 7,86$ & $180,71 \pm 6,20^{* * *}$ & $185,23 \pm 5,36^{\dagger \dagger, \#}$ & 1,106 & 0,173 \\
\hline & $\mathrm{BM}(\mathrm{kg})$ & $68,11 \pm 14,38$ & $71,52 \pm 9,57$ & $79,56 \pm 11,18^{\dagger \dagger, \#}$ & 0,581 & 0,889 \\
\hline & BMI $\left(\mathrm{kg} \bullet \mathrm{m}^{-2}\right)$ & $22,38 \pm 3,56$ & $21,83 \pm 2,17$ & $23,19 \pm 3,18$ & 0,868 & 0,439 \\
\hline \multirow{4}{*}{\begin{tabular}{|c|} 
\\
0 \\
0 \\
0 \\
0 \\
0 \\
0 \\
$\tilde{z}$ \\
$\Sigma$ \\
\end{tabular}} & 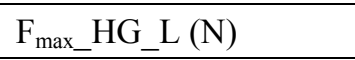 & $336,50 \pm 73,27$ & $332,41 \pm 73,72$ & $428,18 \pm 83,12^{\dagger \dagger, \# \# \#}$ & 0,640 & 0,807 \\
\hline & 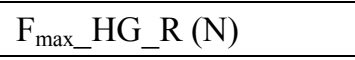 & $355,92 \pm 83,10$ & $385,75 \pm 68,93$ & $472,68 \pm 81,54^{\dagger \dagger, \# \# \#}$ & 0,595 & 0,871 \\
\hline & $\mathrm{F}_{\max \_H G \_S U M}(\mathrm{~N})$ & $692.42 \pm 151,61$ & $718,16 \pm 137,44$ & $900,86 \pm 155,19^{\dagger \dagger, \# \# \#}$ & 0,528 & 0,943 \\
\hline & 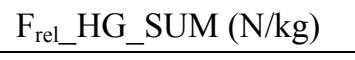 & $10,34 \pm 1.96$ & $10,10 \pm 1,81$ & $11,41 \pm 1,80^{\#}$ & 0,565 & 0,907 \\
\hline \multirow{4}{*}{ 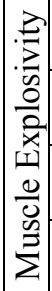 } & $\mathrm{RFD}_{\text {max_HG_L }}(\mathrm{N} / \mathrm{s})$ & $1990,0 \pm 686,1$ & $2607,9 \pm 540,5^{* * *}$ & $3010,2 \pm 569,0^{\dagger \dagger \dagger, \#}$ & 0,486 & 0,972 \\
\hline & $\mathrm{RFD}_{\text {max_H}} \mathrm{HG}_{-} \mathrm{R}(\mathrm{N} / \mathrm{s})$ & $2049,6 \pm 642,7$ & $2345,4 \pm 606,1$ & $3354,9 \pm 639,5^{\dagger \dagger, \# \# ~}$ & 0,728 & 0,664 \\
\hline & RFD max_HG_sum $(\mathrm{N} / \mathrm{s})$ & $4039,6 \pm 1303,5$ & $4953,3 \pm 1066,6^{* *}$ & 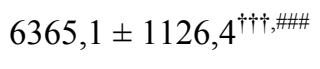 & 0,628 & 0,826 \\
\hline & 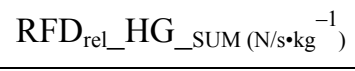 & $59,72 \pm 15,63$ & $69,52 \pm 13,81^{*}$ & $80,94 \pm 15,21^{\dagger \dagger}$ & 0,590 & 0,877 \\
\hline
\end{tabular}

BH - Body height; BM - Body mass; BMI - Body mass index; $\mathbf{F}_{\max \_} \mathbf{H G} \_\mathbf{L}$ - Maximal muscle force for the left hand grip; $\mathbf{F}_{\mathbf{m a x}_{-}} \mathbf{H G} \_\mathbf{R}$ - Maximal muscle force for the right hand grip; $\mathbf{F}_{\mathbf{m a x} \_} \mathbf{H G} \_$sum - Maximal muscle force summarized for the right and the left hand grip; $\mathbf{F}_{\text {rel_}} \mathbf{H G}$ _sum - Relative muscle force summarized for the right and the left hand grip; RFD $\mathbf{m a x}_{-} \mathbf{H G}_{-} \mathbf{L}$ - Maximal explosive muscle force for the left hand grip;

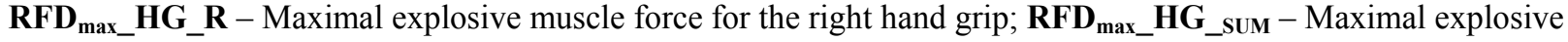
muscle force summarized for the right and the left hand grip; RFD $\mathbf{r e l}$ HG__sum - Relative explosive muscle force summarized for the right and the left hand grip CG vs. WNL, ${ }^{*} \mathrm{p} \leq 0.05 ; * * \mathrm{p} \leq 0.01 ; * * * \mathrm{p} \leq 0.000$; CG vs. WNT, $\dagger \mathrm{p} \leq 0.05 ; \dagger \uparrow \mathrm{p} \leq 0.01$; †† $\mathrm{p} \leq 0.000$; WNL vs. WNT, \# $\mathrm{p} \leq 0.05 ; \# \# \mathrm{p} \leq 0.01$; \#\#\# $\mathrm{p} \leq 0.000$

All examinees voluntarily agreed to participate in the study and oral consent was obtained from the parents and trainers of their clubs. The research was conducted according to the recommendations of the Declaration of Helsinki guidelines for physicians, for biomedical research involving human subjects (http://www.cirp.org/ library/ethics/helsinki/), and with the permission of the Ethics Committee of University of Belgrade Faculty of Sport and Physical Education. Each participant was informed about the goals of this research and personally agreed to participate.

Testing. The maximal isometric contractile characteristics of arms were measured using the isometric handgrip test (HG) with standardized equipment, i.e., a sliding device that measures isometric finger flexor force in accordance with the procedure described earlier [9, 12, 31]. All tests were performed in the Laboratory for Motoric Testing (MIL) at University of Belgrade Faculty of Sport and Physical Education. The standard tensiometric probe (all4gym d.o.o., http://www.all4gym.rs/) with the measurement precision of $\pm 0.01 \mathrm{~N}$ was connected to the force reader. A specially designed software-hardware system (Isometrics Lite, ver. 3.1.1, Isometrics SMS All4Gym, Belgrade) was used for data collection and processing. The force-time signal was sampled at $500 \mathrm{~Hz}$ and low-pass filtered $(10 \mathrm{~Hz})$ using a fourth-order (zero-phase lag) Butterworth filter [19]. The onset of the contraction was defined as the point in time when the first derivative of the force-time curve exceeded the baseline by $3 \%$ of its maximal value. The maximal force was assessed through the maximum of the achieved muscle force level $\left(\mathrm{F}_{\max }\right)$. The maximal rate of force development $\left(\mathrm{RFD}_{\max }\right)$ was calculated as the maximum of the first one derived from the slope of the recorded F-t curve row data [28].

All players were tested after 4-5 minutes of independent warm-up. Each examinee was tested while sitting upright, gripping the measuring device with the hand tested while the arm was extended in the natural posture alongside the body. 


\section{Физиология}

The hand gripping the device was approximately 5 to $10 \mathrm{~cm}$ away from the body. The examinees were not allowed to move from the initial position during the test trial, nor could they lean the hand or the device against the thigh or another part of the body. The power grip, in which all the fingers are flexed around the device, was chosen as it could produce a higher level of force than the other grips (the precision grip, the manipulative grip, or various tool and pinch grips) [32]. Each participant then performed a pre-trial measurement twice, alternating the hands, at medium and sub-maximal intensity, in order to get familiar with the equipment and the testing procedure. After a two-minute rest, the test was carried out. Each respondent was allowed two alternating trials with each hand, with a one-minute pause between trials. All test trial results for all tested variables were recorded in the database, and the better result for each variable was used for data processing [9].

Variables. The participants' anthropometric status was established upon the body height and mass readings. Body mass (BM) was measured using Tanita scales (Body Fat Monitor/Scale TBF-531); all examinees were barefoot and wearing swimming trunks during the measurements.

Body height $(\mathrm{BH})$ was taken using a Martin anthropometer (GPM Anthropometer, Model 100) with a precision of $0.1 \mathrm{~cm}$. The participant was in the standard anthropometric standing position on a solid horizontal surface with the head in the Frankfurt plane, heels brought together and feet apart. The heels, the upper and the lower back had to touch the anthropometer while the head had no contact with the measuring device [26].

Body mass index (BMI) was calculated as the ratio of the mass to height, in accordance with the standard procedure [26].

The contractile properties of handgrip muscle force were assessed exploring two different contractile dimensions: the characteristics of maximal muscle force $-F_{\max }$, and maximal explosive force $-\mathrm{RFD}_{\max }$, using four variables as shown below.

Variables for maximal muscle force characteristics:

1. Maximal muscle force for the left hand grip $\left(\mathrm{F}_{\text {max }}{ }_{\mathrm{HG}} \mathrm{H}\right.$ ), expressed in Newtons $(\mathrm{N})$;

2. Maximal muscle force for the right hand grip $\left(\mathrm{F}_{\max } \mathrm{HG}_{-} \mathrm{R}\right)$, expressed in Newtons $(\mathrm{N})$;

3. Maximal muscle force summarized for the right and the left hand grip ( $\mathrm{F}_{\text {max }} \mathrm{HG}_{-}$sum $)$, expressed in Newtons $(\mathrm{N})$;

4. Relative muscle force summarized for the right and the left hand grip $\left(\mathrm{F}_{\text {rel_}} \mathrm{HG}_{\mathrm{B}} \mathrm{sum}\right)$, expressed in Newtons per kilogram of body mass $(\mathrm{N} / \mathrm{kg})$.

Variables for maximal explosive force characteristics:

5. Maximal explosive muscle force for the left hand grip ( $\left.\mathrm{RFD}_{\text {max }} \mathrm{HG}_{-} \mathrm{L}\right)$ expressed in Newtons per second $(\mathrm{N} / \mathrm{s})$;

6. Maximal explosive muscle force for the right hand grip ( $\left.\mathrm{RFD}_{\max } \mathrm{HG}_{-} \mathrm{R}\right)$, expressed in Newtons per second $(\mathrm{N} / \mathrm{s})$;

7. Maximal explosive muscle force summarized for the right and the left hand grip ( $\mathrm{RFD}_{\text {max }} \mathrm{HG}_{\mathrm{H}}$ sum), expressed in Newtons per second $(\mathrm{N} / \mathrm{s})$;

8. Relative explosive muscle force summarized for the right and the left hand grip ( $\left.\mathrm{RFD}_{\text {rel_}} \mathrm{HG}_{\text {SSum }}\right)$, expressed in Newtons per second per kilogram of body mass $\left(\mathrm{N} / \mathrm{s}^{\bullet} \mathrm{kg}^{-1}\right)$.

Statistics. Statistical methods were used for the basic, multivariate and univariate data analyses. Basic descriptive statistics was calculated for all examined variables (Mean, SD). Normality distribution of the variables was tested by the non-parametric Kolmogorov-Smirnov test (KSZ). Multiple variance analysis (MANOVA) and univariate analysis of variance (ANOVA) were used to calculate the differences between subsamples and the Bonferroni criterion was applied for the comparisons between groups [16]. Interand intra-variable differences were determined at the probability level of $95 \%$, with a p-value of 0.05 . The statistical analyses were carried out using the software packages Excel 2003 (Microsoft ${ }^{\circledR}$ Office Excel 2003) and SPSS Win Statistics 19.0.

\section{Results}

Table 1 shows the results of the descriptive statistical analysis of all studied variables across the subsamples.

Table 2 shows the MANOVA and ANOVA results for the studied variables across the subsamples. It was established that for morphological parameters, there was a general statistically significant difference between the water polo player subsamples and the control group at Wilks' Lambda Value: 0.333, F relation: 11.61, $\mathrm{p}=0.000$. As regards partial differences, the only statistically significant difference between the subsamples was discovered for the BMI variable, with F relation: $1.659, \mathrm{p}=0.196$ (Table 2). 
MANOVA and ANOVA results for the studied variables across subsamples

\begin{tabular}{|c|c|c|c|c|}
\hline \multicolumn{5}{|c|}{ Morphology: MANOVA - Multivariate test } \\
\hline Effects & & Value & $\mathrm{F}$ & Sig. $p$ \\
\hline Grups & Wilks' Lambda & 0,590 & 3,31 & 0,000 \\
\hline \multicolumn{5}{|c|}{ Tests of Between-Subjects Effects } \\
\hline Source & Depended Variable & Type III Sum of Squares & $\mathrm{F}$ & Sig. $p$ \\
\hline \multirow{3}{*}{ Morphology } & $\mathrm{BH}$ & 2351,168 & 26,871 & 0,000 \\
\hline & $\mathrm{BM}$ & 2375,003 & 8,257 & 0,000 \\
\hline & $\mathrm{BMI}$ & 30,888 & 1,659 & 0,196 \\
\hline \multicolumn{5}{|c|}{ HG Muscle Force and Explosivity Characteristics: MANOVA - Multivariate test } \\
\hline Effects & & Value & $\mathrm{F}$ & Sig. $p$ \\
\hline Grups & Wilks' Lambda & 0,333 & 11,61 & 0,000 \\
\hline \multicolumn{5}{|c|}{ Tests of Between-Subjects Effects } \\
\hline Source & Depended Variable & Type III Sum of Squares & $\mathrm{F}$ & Sig. p \\
\hline \multirow{4}{*}{ Muscle Force } & $\mathrm{F}_{\max \_} \mathrm{HG}_{-} \mathrm{L}$ & 196824,4 & 16,730 & 0,000 \\
\hline & $\mathrm{F}_{\max } \mathrm{HG}_{-} \mathrm{R}$ & 252065,7 & 20,546 & 0,000 \\
\hline & $\mathrm{F}_{\max } \mathrm{HG}_{-} \mathrm{SUM}$ & 875864,6 & 19,883 & 0,000 \\
\hline & $\mathrm{F}_{\text {rel_HG_SUM }}$ & 32,5 & 4,681 & 0,011 \\
\hline \multirow{4}{*}{ Muscle Explosivity } & $\mathrm{RFD}_{\max } \mathrm{HG}_{-} \mathrm{L}$ & $1,857 \mathrm{E} 7$ & 25,336 & 0,000 \\
\hline & 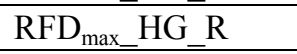 & $3,201 \mathrm{E} 7$ & 40,300 & 0,000 \\
\hline & RFD $_{\text {max_HG_SUM }}$ & $9,508 \mathrm{E} 7$ & 34,395 & 0,000 \\
\hline & RFD $_{\text {rel_HG_SUM }}$ & 7854,1 & 17,607 & 0,000 \\
\hline
\end{tabular}

BH - Body height; BM - Body mass; BMI - Body mass index; $\mathbf{F}_{\max } \mathbf{H G}$ _ $\mathbf{L}$ - Maximal muscle force for the left hand grip; $\mathbf{F}_{\mathbf{m a x} \_} \mathbf{H G} \_\mathbf{R}$ - Maximal muscle force for the right hand grip; $\mathbf{F}_{\text {max }}$ HG_SUM - Maximal muscle force summarized for the right and the left hand grip; $\mathbf{F}_{\text {rel_}}$ HG_SUM - Relative muscle force summarized for the right and the left hand grip; RFD $\mathbf{m a x}_{\mathbf{B}} \mathbf{H G}_{-} \mathbf{L}$ - Maximal explosive muscle force for the left hand grip;

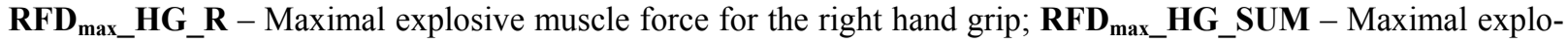
sive muscle force summarized for the right and the left hand grip; RFD force summarized for the right and the left hand grip.

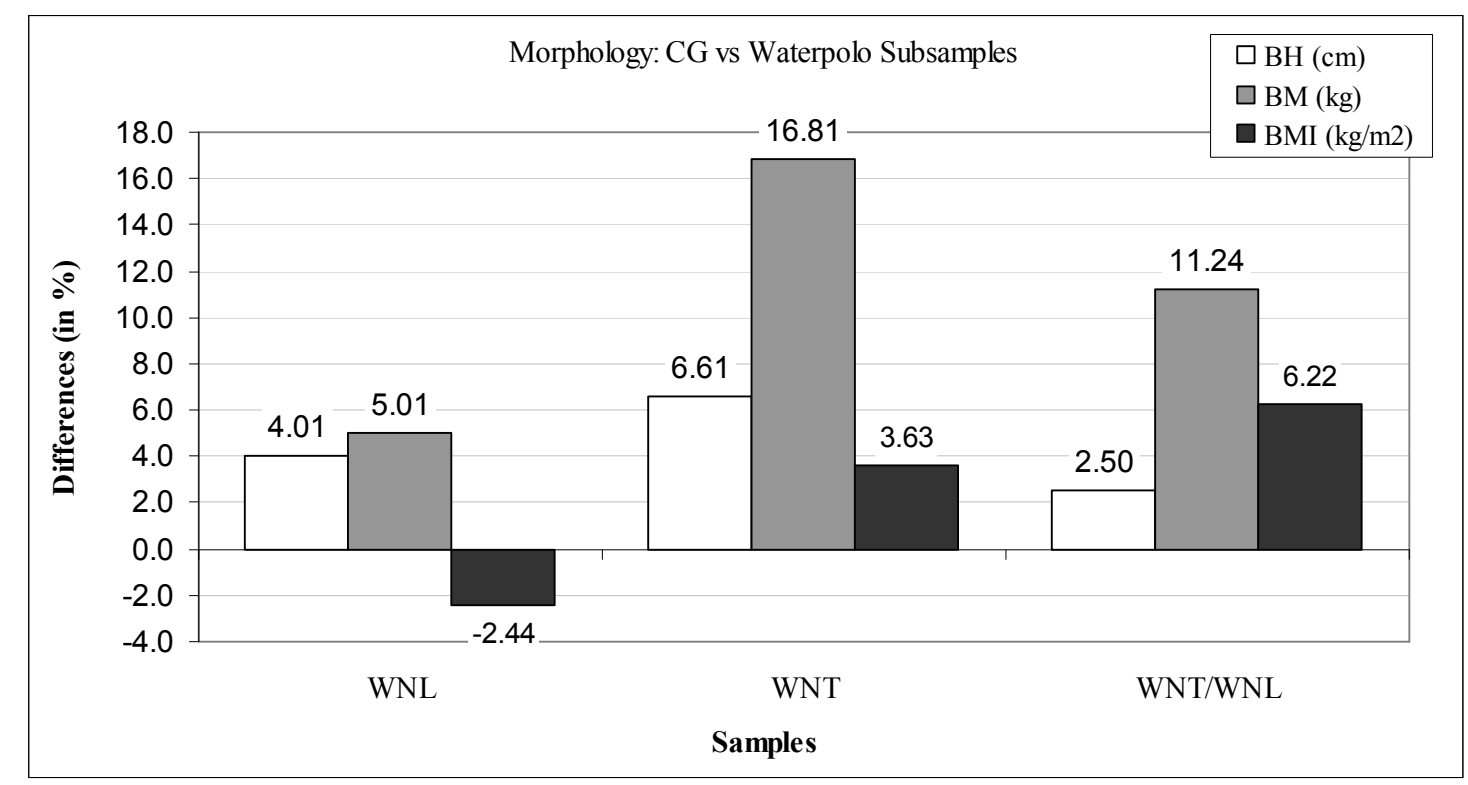

Fig. 1. The results for the relative differences in morphological variables (in \%)

for the WNL and WNT subsamples compared to CG, and for the water polo player subsamples (WNT/WNL) 


\section{Физиология}

With respect to the characteristics of maximal muscle force and maximal explosive muscle force, it was found that there was a general statistically significant difference between the water polo player subsamples and the control group at Wilks' Lambda Value: 0.590, F relation: 3.31, $\mathrm{p}=0.000$. Regarding partial differences, there was a statistically significant difference between the subsamples for all the studied variables (Table 2).

Figure 1 presents the results for the relative dif- ferences in the anthropometric variables (in \%) for the WNL and WNT subsamples defined relative to the control group, as well as the differences across the water polo player subsamples (WNT/WNL).

Figures 2 and 3 show the results for the relative differences in HG contractility variables (in \%) for the WNL and WNT subsamples defined relative to the control group, as well as the differences across the water polo player subsamples (WNT/WNL).

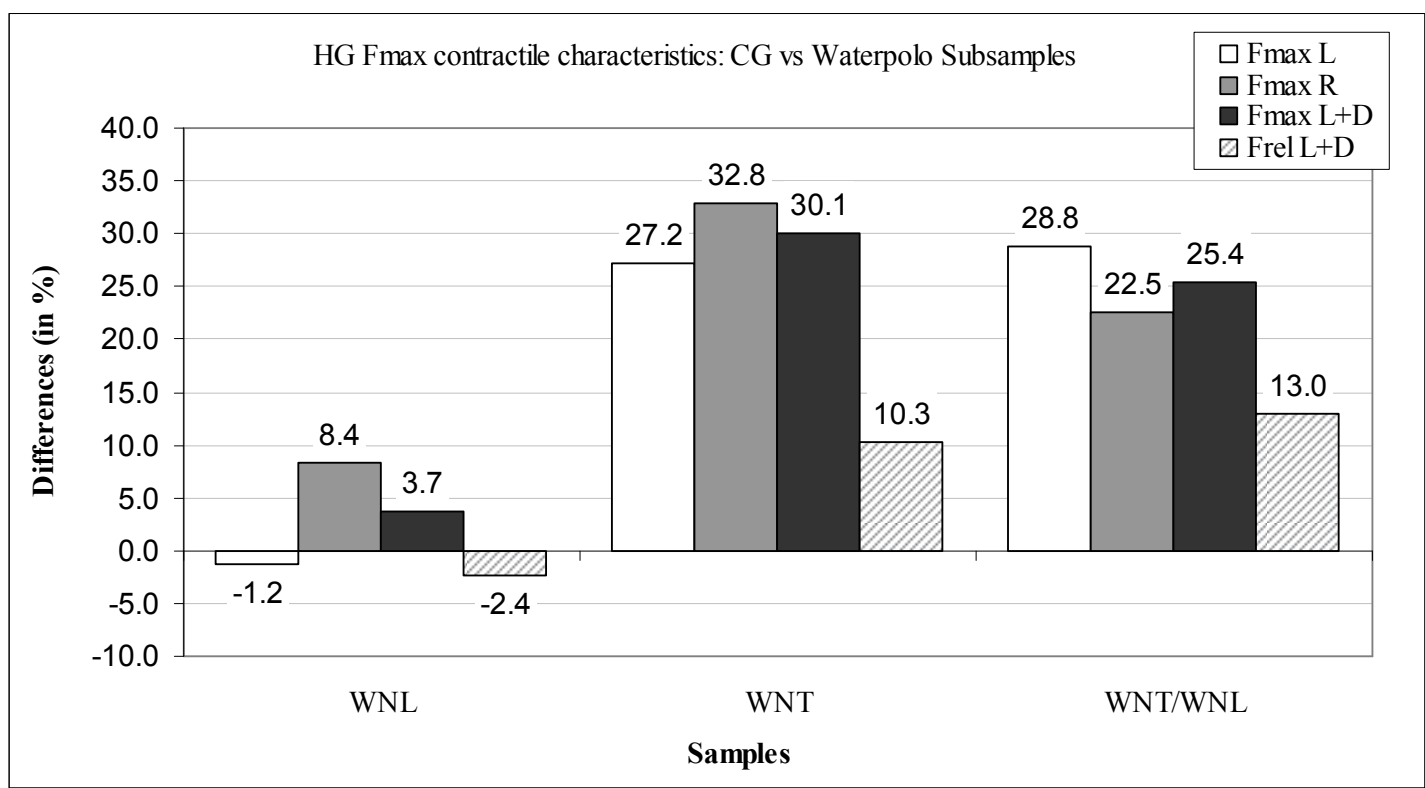

Fig. 2. The results for the relative differences in $H G$ variables for $F_{\max }$ and $F_{\text {rel }}$ (in \%) across the WNL and WNT subsamples compared to CG, and for the water polo player subsamples (WNT/WNL)

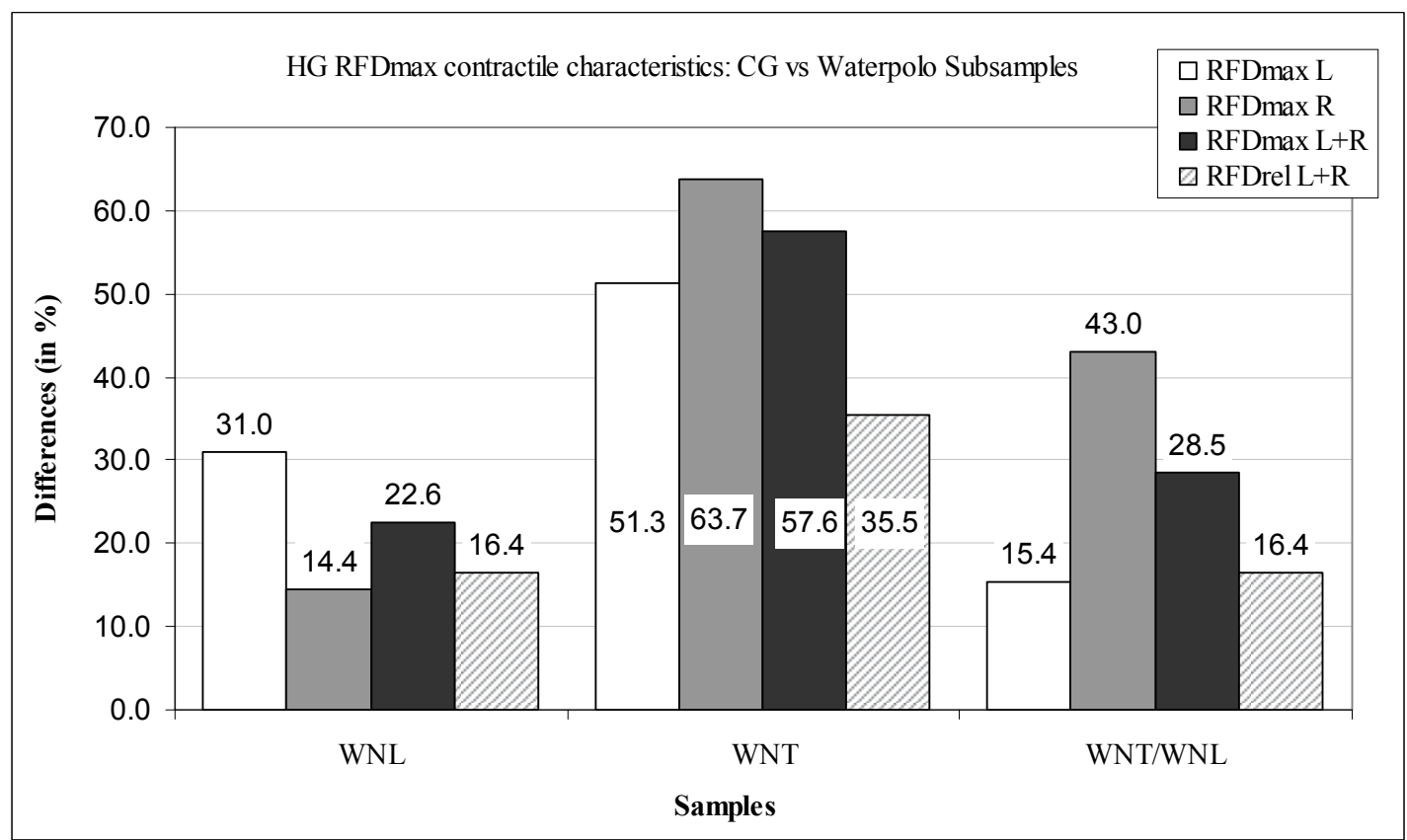

Fig. 3. The results for the relative differences in $H G$ variables for $R F D_{\max }$ and $R F D_{\text {rel }}$ (in \%) across the WNL and WNT subsamples compared to CG, and for the water polo player subsamples (WNT/WNL) 


\section{Discussion}

The research results, obtained using a battery of tests for morphological characteristics (3 variables), maximal muscle force characteristics (4 variables), and maximal explosive muscle force characteristics (4 variables), showed the existence of a general statistically significant difference between the three groups of examinees (Table 2), both in morphological space (Wilks' Lambda Value: 0.333, F relation: 11.61, $\mathrm{p}=0.000)$ and in muscle force and explosivity (Wilks' Lambda Value: 0.590, F relation: 3.31, $\mathrm{p}=0.000$ ).

Regarding the anthropometric parameters across the subsamples (Tables 1 and 2), statistically significant differences were established at the Wilks' Lambda level of $0.590, \mathrm{~F}=3.31$, $\mathrm{p}=0.000$, indicating the differences between the groups in body height $(\mathrm{F}=26.87, \mathrm{p}=0.000)$ and body mass $(\mathrm{F}=8.26, \mathrm{p}=0.000)$; however, no statistically significant difference was found in the BMI variable (Table 2). A partial significant difference (Table 1) was observed between WNT and both WNL and CG for the $\mathrm{BH}$ and $\mathrm{BM}$ variables $(\mathrm{CG}$ vs $\mathrm{WNT}=\mathrm{p} \leq 0.000$; WNL vs $\mathrm{WNT}=$ $\mathrm{p} \leq 0.05)$. Finally, another statistically significant difference was found between CG and WNL for the $\mathrm{BH}$ variable $(\mathrm{p} \leq 0.000)$. These results indicated that the players selected to the national water polo team were taller and heavier compared to the national league players as well as the participants from the control group.

It has already been established that in senior water polo players there is positive correlation between anthropometric characteristics and better competitive performance [14]. Similar results have been reported in senior men playing within the water polo competition system in Greece [30]. Earlier reports have indicated that anthropometric characteristics in elite water polo players have changed in the last two decades in terms of greater height, longer limbs, thinner waist and broader shoulders. At the same time however, body mass and BMI have remained unchanged [20].

These phenomena could be recognized as "a sport-specific morphological optimization process", knowing that the pronounced body height and longer arms allow the player to reach and control the ball and the opponent more efficiently $[10,20]$. Also, it has been established that body height (and presumably body mass) appears to be an important anthropometric parameter for success in short-lasting swimming events [22, 29].

It is important to emphasize that in aquatic sports, BMI not only positively influences characteristic type movements and is an important factor for the impact on hydrodynamic movement and buoyancy of the body, but it also shows a positive statistically significant correlation with the key technical and tactical activities, such as the throwing velocity in the situation with the goalkeeper in the goal. It has been established that physique parameters, that is, body mass index (BMI) $(r=0.477)$, circumference of the arm $(\mathrm{r}=0.479)$, biacromial breadth $(\mathrm{r}=0.531)$ and femur breadth $(\mathrm{r}=0.572)$, correlate with the throwing velocity in situations with the goalkeeper in players of water polo. A well-developed physique has been confirmed as an important factor to achieve high performance in water polo $(\mathrm{p}<0.05)$ [3]. On the other hand, this does not mean that the BMI value in water polo players should increase uncritically, but that it should be within a specific range appropriate for the given sport. In juniors, BMI should range within $23.0-25.0 \mathrm{~kg} / \mathrm{m}^{2}$, and in seniors it may exceed these values and generally fall between $25.91 \pm$ \pm 2.09 and $26.70 \pm 1.7 \mathrm{~kg} / \mathrm{m}^{2}$, or, relative to the playing position, between $25.10 \mathrm{~kg} / \mathrm{m}^{2}$ for goalkeepers and $27.20 \mathrm{~kg} / \mathrm{m}^{2}$ for central backs $[10,20,30]$. These findings were also confirmed in our research, with BMI of $23.19 \pm 3.18 \mathrm{~kg} / \mathrm{m}^{2}$ in WNT (Table 1 and Figure 1). This reinforces the conclusion that body height and body mass are very important factors to consider in the adequate selection of young water polo players regarding the required body status as a morphological potential for achieving top competitive results. As in other sports, early talent identification in water polo can be a key factor in planning the career of young athletes as well as in determining the playing position in the team.

With regard to the studied contractile properties, statistically significant differences were established between the variables explaining maximal muscle force and maximal explosive muscle force in all three groups, such that the WNT players differed from the WNL and CG participants (Table 2, Wilks' Lambda $=0.333, \mathrm{p}=0.000$ ). In addition, the analyses showed that in the given subsamples, $\mathrm{F}_{\max } \mathrm{HG}$ and $\mathrm{RFD}_{\max } \mathrm{HG}_{\mathrm{R}}$, as the variables explaining the maximal muscle force and the explosivity of the dominant hand, were found different with the highest statistical significance (Table 2, $F=20.546$ and $F=40.300$ respectively, $p=0.000)$. Generally, hand muscles, particularly handgrip muscles, participate in all manipulatory activities realized by the cranial part of the body. Thus they have a significant role in habitual, ordinary or specific professional work, as well as in sport activities or in sport testing, 


\section{Физиология}

talent selection or as prognostic criteria $[2,13$, 17]. The results of this research also showed that the given variables for contractility were the most sensitive and that they could be of great value while making preliminary decisions regarding the initial recognition of the physical potential a young water polo player might have [31]. The selection of the hand grip for this study was also based on the fact that the given physiological traits were positively correlated to freestyle sprint swimming performance in boys aged 12 to 14 years, at $\mathrm{r}=0.73, \mathrm{p}<0.01$ [5], and in boys aged 15 years, at $r=0.63$ and $r=0.71$ for dominant and nondominant hand, respectively, at $\mathrm{p}<0.05$ [4].

The most probable explanation as to why handgrip contractility could be used as a potential indicator in talent identification is that it is considered as a suitable phenotype that reflects physical characteristics with relatively high heritability important to mid- and late-life physical functioning, i.e. as a body strength performance potential in adulthood [14].

In their study, Häger-Ross and Rösblad defined [15] define the reference values for hand grip in Swedish children, aged 4-16 years. The comparison between the values given in their study (for the age of 15 years) and our results can suggest that the dominant hand $\mathrm{F}_{\max }$ values for the WNT participants were higher by $13.98 \%$ (Swedish $=413.8 \mathrm{~N}$ vs WNT $472.68 \mathrm{~N}$ ), while the results for WNL and CG were lower by $6.74 \%$ and $14.17 \%$, respectively (Swedish $=413.8 \mathrm{~N}$ vs WNT 385.75 vs CG 355.92 N). However, when the given values were partialized relative to the participants' body mass, the results for the relative handgrip force showed that the children from Sweden had $8.89 \%, 19.64 \%$ and $23.80 \%$ higher relative force compared to our WNT, WNL and CG samples, respectively (Swedish $=6.47 \mathrm{~N} / \mathrm{kg}$ vs $\mathrm{WNT}=5.94 \mathrm{~N} / \mathrm{kg}$ vs $\mathrm{WNL}=5.41 \mathrm{~N} / \mathrm{kg}$ vs $\mathrm{CG}=5.23 \mathrm{~N} / \mathrm{kg}$ ). Based on this comparison, it can be concluded that in water polo, as a sport in which the upper extremities have a predominant role in the ball handling techniques and the duel game, the manifestation of the absolute value of the maximal handgrip force is very high. Obviously, these high muscle force values result from the morphological components, that is, from larger total size $(\mathrm{BH})$ and body mass $(\mathrm{BM})$, rather than from the level of contractility of the body segment itself. On the other hand, these results once again emphasize the importance of high values in anthropometric characteristics in the selection of young water polo players [25].
Another finding of the present research (Fig. 2 and 3) was that the WNT players had higher values of the maximal muscle force and explosivity compared to CG $(32.8 \%$ for $\mathrm{F}_{\max } \mathrm{HG}_{-} \mathrm{R}$ and $63.7 \%$ for $\mathrm{RFD}_{\text {max }_{-}} \mathrm{HG}_{-} \mathrm{R}$ ) and WNL $\left(28.8 \%\right.$ for $F_{\text {max }} H_{G}{ }_{-} L$ and $43.0 \%$ for $\left.\mathrm{RFD}_{\text {max }} \mathrm{HG}_{-} \mathrm{R}\right)$. This suggests that the higher maximal explosive force and maximal muscle force, shown in the handgrip test, may be attributed to compensatory and cumulative training effects on their upper extremities. Besides, technical and tactical competitive activities for water polo players require specific adaptations resulting in better physical and motor abilities, including shooting skills. Better and more efficient hand grip is achieved by the contractile potential to realize rapid and explosive specific motor activities and movements in water polo $[4,6,13]$.

\section{Conclusion}

Multivariate statistical analysis of the results obtained by testing three groups of participants for morphological characteristics (3 variables), maximal muscle force characteristics (4 variables), and maximal explosive muscle force characteristics (4 variables), showed the existence of a general statistically significant difference across the observed subsamples at the level of Wilks' Lambda: 0.333, F relation: 11.61, $\mathrm{p}=0.000$ for anthropometric properties, and Wilks' Lambda: 0.590, F relation: 3.31, $\mathrm{p}=0.000$ for muscle force and explosivity.

With regard to the anthropometric parameters, the water polo players from the U15 national team were statistically significantly taller and heavier than either the national league players or the participants from the control group, all of the same age. Considering contractile characteristics, the results showed that both absolute and relative values of $F_{\max }$ and $R F D_{\max }$ in WNT players were statistically significantly higher than in CG $(32.8 \%$ for $\mathrm{F}_{\max } \mathrm{HG}_{-} \mathrm{R}$ and $63.7 \%$ for $\mathrm{RFD}_{\max } \mathrm{HG}_{-} \mathrm{R}$ ) or in WNL $\left(28.8 \%\right.$ for $\mathrm{F}_{\max \_} \mathrm{HG}_{-} \mathrm{L}$ and $43.0 \%$ for $\left.\mathrm{RFD}_{\text {max }} \mathrm{HG}_{-} \mathrm{R}\right)$. In this respect, it should be mentioned that the significance was higher for maximal explosive muscle force than for maximal muscle force in favor of WNT compared to the other two groups of participants.

Based on the results of the present study, it can be concluded that besides other factors, such as psychological, motivational, motor, or cognitive, both the contractile characteristics of handgrip muscle force $\left(\mathrm{F}_{\max }\right.$, and $\mathrm{RFD}_{\max }$ in particular) and the morphological parameters (BH and $\mathrm{BM}$ ) have a potential advantage in the selection of young water polo players. 
Acknowledgement: The paper is a part of the project "Effects of the Applied Physical Activity on Locomotor, Metabolic, Psycho-Social and Educational Status of the Population of the Republic of Serbia", number III47015, funded by the Ministry of Education, Science and Technological Development of the Republic of Serbia - Scientific Projects 2011-2018 Cycle.

\section{References}

1. Aleksandrović M., Naumovski A., Radovanović D., Georgiev G., \& Popovski D. The Influence of Basic Motor Abilities and Anthropometric Measures on the Specific Motor Skills of Talented Water Polo Players. Facta Universitatis-series: Physical Education and Sport, 2007, no. 5 (1), pp. 65-74.

2. Bao S., Silverstein B. Estimation of Hand Force in Ergonomic Job Evaluations. Ergonomics, 2005, no. 48 (3), pp. 288-301.

3. Vila H., Ferragut C., Argudo F.M., Abraldes J.A., Rodríguez N., Alacid F. Relationship Between Anthropometric Parameters and Throwing Velocity in Water Polo Players. Journal of Human Sport and Exercise, 2009, no. 4 (1), pp. 57-68.

4. Garrido R.J., Silva A.J., Fernandes R.J., Barbosa T.M., Costa A.M., Marinho D.A., Marques M.C. High Level Swimming Performance and Its Relation to Non-Specific Parameters: A Cross-Sectional Study on Maximum Handgrip Isometrics Strength. Perceptual and Motor Skills, 2012, no. 114 (3), pp. 936-948. DOI 10.2466/05.10.25.PMS.114.3.936-948

5. Geladas N.D., Nassis G.P., Pavlicevic S. Somatic and Physical Traits Affecting Sprint Swimming Performance in Young Swimmers. International Journal of Sports Medicine, 2005, no. 26, pp. 139-144. DOI 10.1055/s-2004-817862

6. Davies B., Greenwood E.J., Jones S. Gender Difference in the Relationship of Performance in the Handgrip and Standing Long Jump Tests to Lean Limb Volume in Young Adults. European Journal of Applied Physiology and Occupational Physiology, 1988, no. 58 (3), pp. 315-320.

7. Dopsaj, M., \& Ivanović, J. The Analysis of the Reliability and Factorial Validity in the Basic Characteristics of Isometric F-t Curve of the Leg Extensors in Well Trained Serbian Males and Females. Measurement Science Review, 2011, no. 11 (5), pp. 165-172.

8. Dopsaj M. (2010). Karakteristike Ft krive: Analitički i dijagnostički značaj u sportu. U Stanković, R. (Ur.). Zbornik radova sa: XIV Međunarodni naučni skup FIS Komunikacije, $36-51$.
9. Dopsaj M., Ivanović J., Blagojević M., Vučković G. Descriptive, functional and sexual dimorphism of explosive isometric hand grip force in healthy university students in Serbia. Facta Universitatis-series: Physical Education and Sport, 2009, no. 7 (2), pp. 125-139.

10. Dopsaj M., Aleksandrović M. Basic Anthropometrical Characteristic of Elite Senior Serbian Water Polo Players According to Field Position. International Journal of Fitness (A Journal of the Fitness Society of India), 2009, no. 52, pp. 47-57.

11. Dopsaj M., Madić D., Okičić T. The Assessment of the Acquisition of Various Crawl Style Modes in Water Polo Players with Respect to Age and Competitive Levels. Facta Universitatis series: Physical Education and Sport, 2007, no. 5 (2), pp. 109-120.

12. España-Romero V., Ortega F.B., VicenteRodríguez G., Artero E.G., Rey J.P., Ruiz J.R. Elbow Position Affects Handgrip Strength in Adolescents: Validity and Reliability of Jamar, DynEx, and TKK dynamometers. The Journal of Strength \& Conditioning Research, 2010, no. 24 (1), pp. 272-277.

13. Ferragut C., Vila H., Abraldes J.A., Argudo F., Rodriguez N., Alcaraz P.E. Relationship Among Maximal Grip, Throwing Velocity and Anthropometric Parameters in Elite Water Polo Players. Journal of Sports Medicine and Physical Fitness, 2011, no. 51 (1), pp. 26-32.

14. Frederiksen H., Gaist D., Christian Petersen H., Hjelmborg J., McGue M., Vaupel J.W., Christensen K. Hand Grip Strength: A Phenotype Suitable for Identifying Genetic Variants Affecting Mid- and Late-Life Physical Functioning. Genetic Epidemiology, 2002, no. 23 (2), pp. 110-122.

15. Häger-Ross C., Rösblad B. Norms for Grip Strength in Children Aged 4-16 Years. Acta Paediatrica, 2002, no. 91 (6), pp. 617-625.

16. Hair J., Anderson R., Tatham R., Black W. Multivariate Data Analysis ( $5^{\text {th }}$ ed.). New Jersey, USA: Prentice-Hall. Inc., 1998.

17. Hans-Volkhart U. Complex of an athletic fitness with respect to selection and talent prognosis from a physiological point of view. Medicina Sportiva, 2004, no. 8 (2), pp. 45-52.

18. Koprivica V. Teorija Sportskog Treninga. Multigraf, Beograd, 2002. (in Serbian)

19. Knezevic O., Mirkov D., Kadija M., Nedeljkovic A., Jaric S. Asymmetries in Explosive Strength Following Anterior Cruciate Ligament Reconstruction. Knee, 2014, no. 21, pp. 1039-1045.

20. Lozovina, V., Pavičić, L. Anthropome- 
tric Changes in Elite Male Water Polo Players: Survey in 1980 and 1995. Croatian Medical Journal, 2004, no. 45 (2), pp. 202-205.

21. MacDougall J.D., Wenger H.A., Green H.J. Physiological Testing of the HighPerformance Athlete. Champaign, Illinois: Human Kinetics Books, 1991.

22. Mazza J., Ackland T., Bach T., Cosolito P. Absolute Body Size. Kineanthropometry in Aquatic Sports. Champaign, Illinois: Human Kinetics, 1994, pp. 15-54.

23. Milišić, B. Efficiency in Sport and Training Management Theory. Serbian Journal of Sports Sciences, 2007, no. 1 (1), pp. 1-7.

24. Milishich B. Upravleniye trenirovkoy: uchebno-metodicheskoye posobiye [Management of Training. Educational-Methodical Manual]. St. Petersburg, Olimp Publ., 2007. (In Russ.)

25. Nicolay C.W., Walker A.L. Grip Strength and Endurance: Influences of Anthropometric Variation, Hand Dominance, and Gender. International Journal of Industrial Ergonomics, 2005, no. 35 (7), pp. 605-618.

26. Norton K.I., Marfell-Jones N., Kerr D., Kerr L.E., Carter L.K., Soddington K., Gore C., Lorraine K. Anthropometric Assessment Protocols ( $3^{\text {rd }}$ Ed.), Canbera: Australian Sports Commission, 1998.

27. Platanou, T. Time-Motion Analysis of
International Level Water Polo Players. Journal of Human Movement Studies, 2004, no. 46 (4), pp. 319-332.

28. Sahaly R., Vandewalle H., Driss T. and Monod H. Maximal Voluntary Force and Rate of Force Development in Humans - Importance of Instruction. European Journal of Applied Physiology, 2001, no. 85, pp. 345-350.

29. Silva A.J., Costa A.M., Oliveira P.M., Reis V.M., Saavedra J., Perl J., Rouboa A., Marinho D.A. The Use of Neural Network Technology to Model Swimming Performance. Journal of Sports Science \& Medicine, 2007, no. 6 (1), pp. 117-125.

30. Tsekouras Y.E., Kavouras S.A., Campagna A., Kotsis Y.P., Syntosi S.S., Papazoglou K., \& Sidossis L.S. The Anthropometrical and Physiological Characteristics of Elite Water Polo Players. European Journal of Applied Physiology, 2005, no. 95 (1), pp. 35-41.

31. Wind A.E., Takken T., Helders P.J., Engelbert R.H. Is Grip Strength a Predictor for Total Muscle Strength in Healthy Children, Adolescents, and Young Adults? European Journal of Pediatrics, 2010, no. 169 (3), pp. 281-287.

32. Yan J.H., Downing J.H. Effects of Aging, Grip Span, and Grip Style on Hand Strength. Research Quarterly for Exercise and Sport, 2001, no. 72 (1), pp. 71-77.

Received 12 June 2018

\title{
МОРФОЛОГИЧЕСКИЕ ПАРАМЕТРЫ \\ И ХАРАКТЕРИСТИКИ СОКРАТИМОСТИ МЫШЦ РУК НА ПЕРВОМ ЭТАПЕ ОТБОРА В ВОДНОЕ ПОЛО: РАЗЛИЧИЯ МЕЖДУ ЮНОШАМИ-ВАТЕРПОЛИСТАМИ И КОНТРОЛЬНОЙ ГРУППОЙ
}

\author{
М. Допсай' , 3. Миялковски ${ }^{2}$, Н. Василовски', \\ Н. Чопич ${ }^{3}$, М. Брзакович ${ }^{4}$, М. Маркович ${ }^{1}$ \\ ${ }^{1}$ Белградский университет, г. Белград, Сербия, \\ ${ }^{2}$ Ассоциация Сербии по водному поло, г. Белград, Сербия, \\ ${ }^{3}$ УНИОН - Никола Тесла Университет, г. Белград, Сербия, \\ ${ }^{4}$ Университет Бизнес Академия, г. Нови-Сад, Сербия
}

Цель. Данное исследование призвано подчеркнуть важность сократительной способности мышц рук и морфологических параметров в процессе отбора 15-летних ватерполистов разного уровня подготовленности. Материалы и методы. Настоящее исследование было проведено на выборке, состоящей из 103 человек, 37 из которых принадлежали 
к контрольной группе, 33 представляли игроков национальной юношеской лиги по водному поло, и еще 33 являлись ватерполистами юношеской сборной Сербии по водному поло. Помимо стандартных морфологических параметров были измерены показатели сократимости мышц левой и правой руки (HG_LuHG_R) с использованием двух разных параметров: максимальная мышечная сила $-\mathrm{F}_{\max }$ и максимальная взрывная сила - $\mathrm{RFD}_{\max }$. Результаты. Результаты исследования продемонстрировали наличие статистически значимых различий между тремя группами участников как с точки зрения морфологических параметров (значение Лямбды Уилкса: 0,333; F-критерий: 11,61; p=0,000), так и в отношении мышечной силы и взрывной силы (значение Лямбды Уилкса: 0,590; F-критерий: 3,31; $\mathrm{p}=0,000)$. Более того, полученные результаты показали, что игроки юношеской сборной Сербии имеют более высокие показатели $\mathrm{F}_{\max }$ и $\mathrm{RFD}_{\max }$, чем представители контрольной группы (32,8 \% для $\mathrm{F}_{\max \_} \mathrm{HG}_{-} \mathrm{Rи}$ 63,7\% для $\left.\mathrm{RFD}_{\max } \mathrm{HG}_{-} \mathrm{R}\right)$ и игроки национальной юношеской лиги (28,8 \% для $\mathrm{F}_{\text {max }}{ }_{\mathrm{H}} \mathrm{HG}_{-} \mathrm{Lu} 43,0 \%$ для $\left.\mathrm{R} \overline{\mathrm{FD}} \mathrm{D}_{\max } \mathrm{HG}_{-} \mathrm{R}\right)$. Таким образом, можно предположить, что наибольшие значения показателя максимальной взрывной силы и максимальной мышечной силы могут объясняться адаптивным эффектом тренировок верхних конечностей. Заключение. Результаты проведенного исследования говорят о важности характеристик мышечной силы и взрывной силы $\left(\mathrm{F}_{\max }\right.$ и $\left.\mathrm{RFD}_{\max }\right)$, а также морфологических параметров (рост и вес) при отборе юношей-ватерполистов.

Ключевые слова: водное поло, антропометрические характеристики, юноческий спорт, сжатие руки, максимальная сила, показатель развития силь, спортивный отбор.

Допсай Миливой, $\mathrm{PhD}$, профессор, анализ и диагностика в спорте и физической культуре, факультет спорта и физической культуры, Белградский университет. Сербия, 11000, г. Белград, Студенческая площадь, 1. E-mail: milivoj@eunet.rs.

Миялковски Зоран, магистр наук, главный юношеский тренер, Ассоциация Сербии по водному поло. Сербия, 11000, г. Белград, ул. Сметанина, 2. E-mail: zoran.mijalkovski@gmail.com.

Василовски Ненад, магистр наук, главный детский тренер, Ассоциация Сербии по водному поло. Сербия, 11000, г. Белград, ул. Сметанина, 2. E-mail: kolewp@gmail.com.

Чопич Неманя, $\mathrm{PhD}$, доцент, диагностика в спорте, УНИОН - Никола Тесла Университет, факультет спорта. Сербия, 11000, г. Белград, ул. Кара Душана, 62-64. E-mail: nemanjacopic@, yahoo.com.

Брзакович Миодраг, $\mathrm{PhD}$, профессор, менеджмент, Университет Бизнес Академия, факультет прикладного менеджмента, экономики и финансов. Сербия, 21000, г. Нови-Сад, ул. Владимира Перича-Вальтера, 4. E-mail: miodragbrzakovicfmmsp@gmail.com.

Маркович Милан, аспирант, анализ и диагностика в спорте и физической культуре, факультет спорта и физической культуры, Белградский университет. Сербия, 11000, г. Белград, Студенческая площадь, 1. E-mail: mm_milanm@yahoo.com.

Поступила в редакцию 12 июня 2018 г.

\section{ОБРАЗЕЦ ЦИТИРОВАНИЯ}

Dopsaj M., Mijalkovski Z., Vasilovski N. et al. Morphological Parameters and Handgrip Muscle Force Contractile Characteristics in the First Selection Level in Water Polo: Differences Between U15 Water Polo Players and the Control Group // Человек. Спорт. Медицина. 2018. - T. 18, № 3. - C. 5-15. DOI: 10.14529/hsm180301

\section{FOR CITATION}

Dopsaj M., Mijalkovski Z., Vasilovski N., Ćopić N., Brzaković M., Marković M. Morphological Parameters and Handgrip Muscle Force Contractile Characteristics in the First Selection Level in Water Polo: Differences Between U15 Water Polo Players and the Control Group. Human. Sport. Medicine, 2018, vol. 18, no. 3, pp. 5-15. DOI: $10.14529 / \mathrm{hsm} 180301$ 